\title{
Chapter 1 \\ Money: The Greatest Innovation \\ in the History of Humanity
}

\section{The Essence of This Book}

Money is a central part of everybody's life and every society and has been more important for humanity than the wheel, the printing press, the steam engine, and the Internet. Money is one of the greatest innovations in our history! I therefore decided to write this book about money.

Not only is money one of the greatest innovations, it is also currently being radically transformed in a way that has not happened in centuries. The last radical or even paradigmatic transformation of money came in the seventeenth century when the Riksbank of Sweden and Bank of England introduced the first money provided by central banks. Yes, we had had money-in the form of shells, stones, rings, coins, bills, or other forms - provided and backed by kings, emperors, and other head of states a long time before this. But this is when money became what it is today, i.e., a guarantee of value provided by a central bank, backed by a state, and issued in the form of bills and coins. What we simply call cash. No matter if we use US dollars, euros, Chinese RMBs, Russian rubles, or Swedish crowns, the basic form was introduced in the seventeenth century and is still an important part of many societies.

We now see, however, that the concept we call cash is challenged! We are actually discussing whether we may see entire economies without cash. The idea of cashless societies is not new, but it has not really been realistic until today as digitalization is reshaping fundamental dimensions of our societies, where money is one of them. And why should not money be transformed? Most things come to an end, and it is likely this may happen to cash as well.

This book explores how a cashless society is developed and look like by studying Sweden. I know that Sweden is not like other countries and that all the insights from understanding Sweden cannot be exported to other countries. This is not my aim. I aim to explain what made Sweden becoming a cashless society, to provide a discussion of challenges and opportunities that lies ahead, and to ignite much needed 
discussions of how less cash-or even no cash-will transform our economies. Because this is a societal challenge we must learn to master.

This is a book about the abdication of the king formerly known as Cash. The projected abdication of Cash in Sweden is expected to happen in 2023 AD.

I hope you will enjoy reading this book and that it evokes new thoughts and engaged debates about the future of cash.

\section{Money: The Center of Development Since the Birth of Humanity}

Money in some form has probably been at the center of trade and business since the birth of humanity. Unless favors are based entirely on charity or an eternal promise to make good in return, some sort of payment system is needed to stimulate trade and thereby enable specialization and prosperity. Even an economic system entirely based on nonpecuniary trade needs agreements on terms of trade, for instance, how to make a fair trade between rice and milk, which in essence lays the foundation for one important feature of money, i.e., unit of account. If 1 kilo rice can be exchanged for, let's say, 2 liters of milk, the system has set a value on both products and this value can then be accounted for via a monetary system. And such monetary systems have proven to be important for development throughout the history of humanity. I will argue that they are a critical part of the human history and development.

From time to time, there are discussions of what can be said to be the greatest innovation in the history of humanity. There are several potential candidates for this prestigious award, and it is a difficult task to judge this. What should be the yardstick and how do we compare innovations made several thousand years apart? All in all, this is not a fair contest. We will most likely overestimate the value of innovations that are recent since they have had a strong impact on our own lives while underestimating those made in ancient history. Bearing this in mind, I will nevertheless make a case for one important innovation: money. I assume this did not come as a great surprise given the topic of the book.

Commonly mentioned candidates for the prestigious award of being the greatest innovation of all kind include fire, the wheel, the nail, optical lenses, the compass, paper, gunpowder, the printing press, electricity, the steam engine, the internal combustion engine, the telephone, the light bulb, penicillin, vaccination, airplanes, contraceptives, rockets, nuclear fission, semiconductors, the Internet, and many others. The list is endless, and the answer you get will depend on who you ask.

An article in National Geographic ${ }^{1}$ points out the ten most important innovations by referring to a list provided by the US librarian of Congress. According to this article, the ten most important innovations in the history of humanity are the printing

\footnotetext{
${ }^{1}$ http://www.nationalgeographic.com/magazine/2017/06/explore-top-ten-innovations/
} 
press, the light bulb, the airplane, the personal computer, vaccines, the automobile, the clock, the telephone, refrigeration, and the camera. The list duly mentions that the task is difficult and that there are no easy and unquestionable answers to this question.

It is remarkable that when searching for conclusions about the most important innovations in the history of humanity, there is a distinct bias toward technological innovations. This bias is perhaps a natural effect from the fact that the world still is in its industrial society era where manufacturing of physical goods is the most important objective for societies and companies. The industrial era from late 1800s all through the 1900s seems to have made us strongly favor and acknowledge hard technologies over social innovations.

It is without doubt that technological innovations have changed the history of humanity to a large extent, but it would be outright incorrect if we did not see the importance of social innovations when trying to understand how innovations have changed the history of humanity. I would even argue that social innovations have played a greater role in this respect than technological innovations.

One example of a list of innovations that also looks at social innovations-i.e., ideas that change how we live and how we understand life-is that provided by the Startup Guide. ${ }^{2}$ This list includes not only the examples mentioned above but also social ideas such as language, trade and specialization, farming, legal systems, the alphabet, and (here it comes) money. It would be unfair and incorrect if we did not add ideologies like socialism and capitalism to this list. Just think of how political ideologies like socialism and capitalism-for good and bad-changed the world during the twentieth century. The way we understand the global world is tightly connected to an ideological-and unfortunately often also political and military-fight between social ideas of how we should structure our societies. Leaving the judgment of which ideology that is superior to you, I simply conclude that innovation of ideas has had and have a strong influence on our societies. And I have not even mentioned religion! Well, this is not a book about religion or political ideologies so I will stop here and turn to the topic of this book-the social innovation called money.

So, my argument is that one of the most important social innovations in the history of humanity is money. But what is money? A common definition of money is: "A current medium of exchange in the form of coins and banknotes; coins and banknotes collectively." "3 If you ask a central bank, they could define it as: "Money in the modern economy is just a special form of IOU, or in the language of economic accounts, a financial asset." ${ }^{\prime 4}$ The simple definition of central bank money is then that it is a document acknowledging that the central bank owes the holder the amount that is specified on the bill or coin. A bill is an IOU from the central bank to the holder. It

\footnotetext{
${ }^{2}$ http://startupguide.com/world/the-40-greatest-innovations-of-all-time/

${ }^{3}$ https://en.oxforddictionaries.com/definition/money

${ }^{4}$ http://www.bankofengland.co.uk/publications/Documents/quarterlybulletin/2014/

qb14q1prereleasemoneyintro.pdf
} 
should be acknowledged that this is a strong simplification-probably too simplified if you ask an economist. ${ }^{5}$ But this is what money is-a promise that the bills or coins can be exchanged with something - a cup of coffee or a trip to Chiang Mai in Thailand, issued by a central bank which is backed by a government.

But, as stated previously: "Money is first and foremost a social convention, which emerges to build trust among strangers in their economic transactions, both intertemporal and in spot markets. A convention of monetary exchange facilitates valuable intertemporal exchanges that would not occur otherwise." ${ }^{6}$ Money is a tool that help people make transactions in a trustful way. If I hand over my bike to a stranger and he gives me five 100 euro notes in exchange, I can relax. And be happy because that old bike was not worth 500 euros if you ask me. Money enables us to make transactions in a safe way even with people or companies we do not really trust. This is great. In fact, it is a strike of geniality.

And money is one main explanation to how our societies work today. The inventions of writing and grammar made it possible to communicate across distances and over time. Money made it possible to store value and allow exchanges to be independent of time. In a true barter economy, transactions need to be done by exchanging goods and services in real time with the exception that mutual trust could allow exchanges to become independent of time. I can give you 100 kilo of wheat if I can trust you give me 50 kilo of corn 2 months from now. But money is even better since it completes the transaction immediately instead of in 2 months. Money is a prerequisite for trade which stimulates specialization and further trade and so on. Our modern economy is built on trustworthy money and has money as one of its fundamental foundations.

Money is fundamentally an idea that if you provide something - a good or a service-to someone today, you want to trust that someone will provide something for you tomorrow. Nobody-or at least very few-wants to be the person who always gives and gives but never gets something in return. At least not in the long run. We want to trust that giving something away today will mean that we get something back tomorrow. This is a simple but very basic need for everyone. And money is the solution to this problem. If you get money for that which you provide today, you can use this money and buy what you need tomorrow. It is as simple-but at the same time extremely difficult-as that.

The economists would say that effective money must meet three functions. First, money should function as a means of payments - it should enable people to make economic transactions. Second, it should be a unit of account or standard of value-it should help us compare the value of completely different products and services. This makes it possible to compare the value of a cup of coffee and a haircut and thus simplifies our lives and choices. Third, it should serve as a store of value-we should be certain that the value of the money we have is stable. We do

\footnotetext{
${ }^{5}$ For a discussion of what money is, see, for example, Krugman, Paul (2010), "What Is Money?," New York Times, December 15th edition.

${ }^{6}$ http://www.riksbank.se/Documents/Rapporter/POV/2017/rap_pov_artikel_6_170120_eng.pdf
} 
not want our well-earned savings of 1000 dollars to buy us a great computer today but only a half-bad computer in a month. And, in the long run, it is not good if the opposite occur either since this will tend to stifle our economies. So, stability of the value of money is critical for it to be effective as a way of making payments. Note that I am talking about money as a tool for economic exchange, i.e., for making payments. There is a much more complex story of the role stability of money has for our economies as a whole, but that is not the topic of this book.

If you are speculating in the value of money-USD or euro-you of course want fluctuation of its value, but that is a different story too. Fluctuation of value makes it possible to gain - just follow the old trick about buy low and sell high-which is critical for investors. Note that doing it the other way around-buy high and sell low-is not recommended even if we daily see that even very professional investors do this. But enough about speculation, let us turn back to money as a tool for exchange.

The functionality of money, i.e., trust in a future return, is arguably (at least if you ask me) one of the most important innovations in the history of humanity and what has enabled us to create advanced societies built on, for instance, technological innovations. Without money there would most likely be very few, if any, technological innovations. Without solid proof, this book is built on the firm belief that money is one of the most important innovations in the history of humanity and therefore worth exploring further, especially as the shape of money is currently being transformed into something very different from what we are used to.

Note that money will not disappear if cash disappears! This is often the belief and an indication of the strong influence cash has had on our societies. Many tend to believe that cash is money, but cash is just one form of money even if it has (or had if we talk about Sweden) a critical role in our societies. People tend to think of money only in the form of cash which is partly correct but in the end ultimately incorrect. This book shows that money will remain but cash may disappear. You can think of cash as one of several instruments to provide money and to enable payments. Others include, for instance, card payments, mobile payments, checks, coupons, and Internet banking transactions.

There are in fact several fundamentally different forms of money today. The most important form is money backed by a central bank which come in the form of bills or coins. This is a debt the central bank has to the holder of a bill or a coin. This is also what we tend to associate with money even if this form is challenged and thus is losing its predominance in the field of money. The value of this form of money is in Sweden around $1 \%$ of GDP and can therefore no longer be seen as an important form of money. It still plays an important role, of course, but not the central role it used to have. Another and more important form of money is bank money, i.e., money that rests in bank accounts and represents a debt from the bank to you. This form of money-what is called bank money-is much more important than cash in our modern societies.

Bank money is actually created by banks as they use collateral that is monetized by being a security for loans that banks provide to companies and people. A bank can create new money by lending to a person with this person's house, apartment or 
business as security. If the person lends 100,000 euros and uses her house as security, the economy has been boosted with 100,000 new euros. This story can continue as long as the bank makes good judgment of the value of the collateral and does not hand out loans with poor security. But as history has proven over and over again, this ultimately tends to lead to crashes where the newly created money disappears, banks make credit losses, and people and/or businesses end up in financial distress. Bank money is fluctuating depending on the belief in the general economy and the bank's ability to make correct decisions on the future value of the securities they use to provide loans.

A third form of money is virtual currencies which rests on fundamentally different systems and processes constituting trust and value. Yet others include central bank digital currencies (CBDC) and local currencies not backed by a central bank. But we will leave those aside for the time being and come back to them later in a discussion of paradigms of money.

We conclude that cash is being challenged as a central tool for making payments and that our traditionally cash-based societies are being transformed into-more or less - cashless societies. This is what the book aims to understand by looking at how Sweden - the most cashless society in the world - has been transformed during the last decades. The book will not merely do that but also take a look into the future and discuss what we may expect in the coming years.

I acknowledge that the use of cash still is high — and perhaps even increasing - in many parts of the world which shows that development always has to be understood in its context. There may be economic factors influencing the development which has been seen in Spain where cash withdrawals decreased substantially after the financial crisis in 2008 but started to grow again in $2013 .^{7}$ But also governmental plans to reduce cash which we saw in India in $2016^{8}$ where around $86 \%$ of the cashin-circulation was declared invalid almost overnight as an attempt to reduce tax evasion and the use of black money in the economy. The attempt did not prove successful, however, as Indians seem to prefer cash and did not change habits overnight. ${ }^{9}$ We also tend to see that the use of cash differs between rather similar countries like Sweden and Germany where cash still is very popular in Germany while at the same time disappearing in Sweden and between urban and rural areas where the use of cash tends to be higher in rural areas than in larger cities. In essence, the development in Sweden must be understood through understanding the context of Sweden.

\footnotetext{
${ }^{7}$ https://sdw.ecb.europa.eu/reports.do?node $=100000760$

${ }^{8}$ https://www.bbc.com/news/world-asia-india-37974423

${ }^{9}$ https://qz.com/india/1 127614/demonetisation-indias-grand-plan-to-go-cashless-has-failed/
} 
And to understand the presence and the future, we must also understand the past. This is what I will turn to now.

Open Access This chapter is licensed under the terms of the Creative Commons Attribution 4.0 International License (http://creativecommons.org/licenses/by/4.0/), which permits use, sharing, adaptation, distribution and reproduction in any medium or format, as long as you give appropriate credit to the original author(s) and the source, provide a link to the Creative Commons licence and indicate if changes were made.

The images or other third party material in this chapter are included in the chapter's Creative Commons licence, unless indicated otherwise in a credit line to the material. If material is not included in the chapter's Creative Commons licence and your intended use is not permitted by statutory regulation or exceeds the permitted use, you will need to obtain permission directly from the copyright holder.

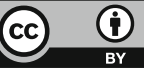

